
http://dx.doi.org/10.33474/j-reall.v1i1.5424 Vol. 1 | No. 1 | Februari 2020 | Hal. 1 - 11

\title{
Designing nahshorna bilingual media for nahwu-shorof basic learning
}

\author{
Iin Baroroh Ma'arif ${ }^{1}$, Akhmad Kanzul Fikri $^{2}$, Atik Husna ${ }^{3}$ \\ ${ }^{1,2,3}$ English Departement Education, Unwaha University, Indonesia \\ 1iinmaarif@unwaha.ac.id, ${ }^{2}$ akhmadkanzulfikri87@gmail.com, ${ }^{3}$ ucenaatik@gmail.com \\ *) correspondence: iinmaarif@unwaha.ac.id
}

\begin{abstract}
This study is conducted on the basis of researcher's observation that students are lack of interest of study in learning Arabic grammar, namely Nabwu-Shorof basic learning. Students have good basic on English ability. The objective of this study is to find out the feasibility of designing "NahShorNa" bilingual media for Nabwu-Shorof basic learning for students. This study involved 12 students. The subjects of this study are second grade students of An-Nashriyah Islamic Boarding School. This study used qualitative data and used Research and Development (R\&D) Research Design. The instruments of this study used observation, interview, questionnaire and documentation. The study focused on reading ability. The findings of the study that are the result of media validation is $88 \%$ score in very good category, the result of two materials validation is interesting categories, English material is $75 \%$ score in pretty good category, the Arabic material is $73,75 \%$ score in pretty good category and the result of user validation in preliminary field study is "Good" response.

Keywords: NahShorNa media; Bilingual; Nahwu-Shorof
\end{abstract}

\section{INTRODUCTION}

Education in Indonesia is applied by new innovations for improving good quality. Education is as Learning of Cognitive (Knowledge), Affective (Attitude) and psychomotor (Creativity) for the students from one generation to the next generation by learning, training and research. Education can be guided by teacher and can be learnt autodidact. (As cited by Sari, 2017) according to Croanbach in his book, Educational Psychology said that, "Learning is shown by a change in behavior as a result of experience". It means that a good study is by experiences, the students use the five senses. Nowadays, education does not only learn one language but also to learn more than one language.

There are two kinds of education, Religion Education and Universal Education. In Arabic Language, Education as"Tarbiyyah (تَرْبِيَّة)" by fi'il madhi "Rabba(رَبَّى)" which has meaning "Educate". In Arabic Language, Religion Education as Tarbiyyah Islamiyah.

In Arabic Learning, there is one of main material such as Arabic learning of Nabwu-Shorof, Arabic language, Islamic classical books, etc. Nahwu-Shorof is as main learning at Islamic Literature, first learning for understanding of Islamic Literature, morphology learning and Arabic Grammar. Beginning from Arabic Language up to Arabic Grammar knowledge, they need the Nabwu-Shorof. For example, Go-Went-Gone (English Learning) ذَذَبَ- يَذْهَبُ (Arabic Learning).

In developing period, Nabwu-Shorofb become curriculum and lesson in the Islamic Boarding School (Pondok Pesantren), Islamic Senior High School (Madrasah Aliyah), Islamic Junior High School (Madrasah Tsanawiyah) and Islamic Elementary School (Madrasah Ibtidaiyah).

One of them is in Bahrul 'Ulum Islamic Boarding Schools, Tambak beras, Jombang which learned about Nabwu-Shorof. Most of subjects assume that Nabwu-Shorof sscience is boring because it uses many books, abstract learning and there are many Nabwu-Shorof books that are still difficult to understand with Arabic grammar. Most of students can speak Arabic but the grammar is error because the basic of education is religion because most of them study in Islamic Junior High School and Islamic Senior High School. Actually, English grammar and Arabic grammar are same. But, 
most of the students can not correlate each of them. As long as, learning Nahwu-Shorof uses discussion method, memorizing method, reading method, lecturing method and speaking method. For speaking method, it makes the students feel bored to learn.

The purpose of this study is to increase student interest and add facilities when they study, so that the original primary learning in Arabic is not lost. Therefore, the use of these media makes learning fun and the teachers can visualize the material and practice using the media. By the background, researcher plans to research Designing "NabShorNa" Bilingual Media for Nabwu-Shorof Basic Learning which is designed by using Adobe Flash CS5 software as more interactive and effective without disappearing the authentic of Kitab Kuning.

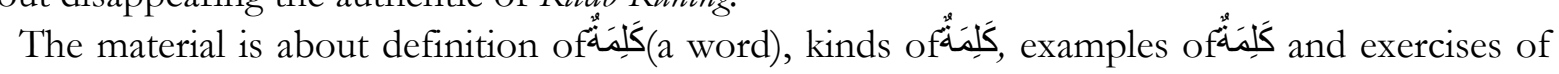
كَلِمَنُ

\section{METHODS}

This research took Research and Development $(\mathrm{R} \& \mathrm{D})$ as it aims was to develop a new product and modification term of previous study as a bilingual media in Nahwu-Shorof basic learning.

Development research is a process of designingand assessment of products that is used in learning process. In another definition, Research and Development (R\&D) defined research development is as a kind of purpose to result in the product, ended with evaluation and feasibility of the product based on Sugiyono (as cited in Anggraini, 2014). Actually, Research and Development (R\&D) is designing new product or developing the product. The product is not only hardware type, but also software type.

Steps of Research and Developing on NahShorNa media by using Adobe Flash CS5 is adopted by Borg and Gall Development. This procedure is chosen because it is simple and more detail. This is Borg and Gall research procedure: Research and Collecting Information

This are steps that done by observation and field study. These are: The observation is done to know the learning process in Nabwu-Shorof learning. According to Sugiyono (2014) said that observation is done to know how process the students learning in the classroom and how the students activities is. Moreover, Observation is able to evaluate for the teacher, media, situation and condition of learning, interaction to the students and others. Observation is done when research in the classroom and the out classroom. The researcher started by giving questionnaire to find the samples of research. Besides, the researcher prepared interview to the teacher and to the some students. This study is done for helping the researcher to collect and review the data for learning media and develop it. Planning in this development includes the preparation of material, designing the questionnaire, designing of the product and all the tools needed. In Developing Preliminary Form of Product step, the researcher designed the product step by step accordance with previous planning. The media used by bilingual (Arabic Language and English Language). In Preliminary Field Testing, this step, the researcher asked to the material experts and media expert to give evaluation.

In Main Product Revision, this step is done after evaluation from expert if it is needed. In Main Field Testing step, this step is done to the students especially for the second grade of students. The researcher just tested 12 students of grade two in the Islamic Boarding School accordance by questionnaire is given for grade two. They used the media for practice. In Operational Product Revision step, this step is done by observation and evaluation from the students. The response from the students is good. So, there is no revision. In Operational Field Testing step, the researcher used small testing. So, there is no field testing. In Final Product Revision step, they are final result of research. In Implementation step, it is important by researcher because the researcher thought that this media must use by others, not unilateral. The knowledge is not by self, but it is for dissemination so that beneficial and useful.

The research will be conducted at An-Nashriyah Islamic Boarding School in Tambak beras, Jombang, East Java. The period of research is from April 22 to May 23, 2019. In the Research and Development, it was conducted by small group test. The researcher determined that the object of 
study includes: three experts on test validation and 12 students in small group test. Object of this research is the feasibility about Design "NahShorNa" bilingual media to help students for NabwuShorof basic learning and Implement "NahShorNa" bilingual media for Nabwu-Shorof basic learning. The research was conducted at An-Nashriyah Bahrul 'Ulum Islamic Boarding School, Tambakberas, Jombang, East Java.Second grade has 22 students. In the Research and Development (R\&D), it was conducted by three test steps: one by one test, small group test, and field test. Above the describing, the researcher focused on Second Grade in An-Nashriyah Islamic Boarding School by small group test.

\section{RESULTS AND DISCUSSION}

Designing NahShorNa bilingual media for Nahwu-Shorof learning in An-Nashriyah Islamic Boarding School Bahrul 'Ulum Tambakberas Jombang followed three parts: The first is the result of developing product. The second is the result of expert validation and revision. The third is the result of final product.

\section{The result of developing product}

The researcher adapted by Borg and Gall's Development. In this part, the researcher will discuss some the steps.

1. Research and information collecting In these steps, the research conducted the field study and did observation. Observation is done at the students of second grade in the An-Nashriyah Islamic Boarding School. It is to know that how learning process and the problem Nabwu-Shorof learning in the class. In this observation, the researcher needed the instrument to help finding the problem. The observation was done by interview and give questionnaire to the several students and Nabwu-Shorofteacher at second grade.Based on observation, the researcher concluded that :

a. In An-Nashriyah, Nahwu-Shorof learning uses book media.

b. The researcher conducted the research at second grade of An-Nashriyah because NahwuShorof is learned at second grade. The researcher did not choose at First Grade in AnNashriyah because they adapted and adjusted with learning in the school and in the Islamic Boarding School. Although there were lesson of English Language and Arabic Language. The researcher did not conduct on third grade because the level of third grade is more extensive that first grade and second grade.

c. The researcher chose Nahwu-Shorof material because it is basic main of sciences for Arabic Literature learning. Now days, an expert of Nahwu-Shorof material is decreasing, moreover almost of lost authentically. The researcher used basic material because the NahShorNa media was a contribution for media and has function as stabilization of Nabwu-Shorof learning at first grade.

d. The researcher used Bilingual because in An-Nashriyah will be applied bilingual (English Language and Arabic Language). The English Language and the Arabic Language are international language that it is known by everybody.

e. NahShorNa media used multimedia because the Nahwu-Shorof learning still uses book media so that the interesting response by students is low and not interactive. Whereas now days, the students are demanded to be up to date. Because of it, the researcher conducted the material by multimedia with authentic of Arabic literature that it was creation of expert of NahwuShorof in the traditional period.

f. The Researcher asked several students to interview them that how Nahwu-Shorof learning in the class. About 50\% students of second grade are interested in Nabwu-Shorof learning. Based them, the learning is interest about the method by using the book. For example discussed method, singing a song method, explanation method by speaking and did not using technology. It concluded that the learning is good by using that method. However about 
$50 \%$ students were not interested about the learning. They assumed that Nabwu-Shorof Learning is boring and making passive learning so that they can be sleepy in the class.

g. The students have problem in the media. For this time, the learning using book media did not using technology media. Actually in the first grade of Islamic Boarding School was there learning. But, at the second grade was not fluency basic Nabwu-Shorof learning and the students were often forget. The researcher gave the teacher a questionnaire and several students. After the students were known that how interested Nabwu-Shorof Learning, they who are not interested the learning, they will take for research. The researcher was also interview for several students to know the response of the learning to get the problem.

h. Actually, there is a projector in Islamic Boarding School. The students really like to learn by using technology media that supported the learning. Opportunely, in first grade they learned Arabic and English language. So, it can combine the two languages because the planning of the Islamic Boarding School will use two language for future. The material is very basic because the students still forget about the difficult word in Nabwu-Shorof learning. So, the researcher combined two languages so that the students can apply and learn easily.

\section{Planning}

After knowing about the problems, the researcher planned for designing media other books. Many Islamic Boarding Schools used books so that the students do not apply the material. From the questionnaire of need analysis, they were taken for samples of research by Random sampling and by opinion of the teacher of 12 students of second grade An-Nashriyah. In this step, the researcher planned about the material that it is used. The researcher conducted the basic material because the study must be basic learning first so that it can continue the next material. After conducted the material systematically based on syllabus. Next, the material was conducted in the multimedia using Adobe Flash CS5 because it is practical and did not need more capacity. The researcher used observation, interview to the several students, giving questionnaire of Need Analysis to the second Grade students of An-Nashriyah, giving writing questionnaire and record interview to the teacher of Nabwu-Shorof in second grade AnNashriyah. Flowchart, Storyboard and Software is needed on the planning part for making the media. The software to make NahShorNa media is Adobe Flash CS5. Adobe Flash CS5 is software that made animation two dimensions so flash is used for CD interactive and animation effect on website. Adobe flash has view large so it needs a lot hard disk. The media used Adobe Flash CS5 because it used view data, used action script 2.0 and support mp4.

3. Develop Preliminary From of Product.

The researcher designed NahShorNa media by step using bilingual. The steps of developing NahShorNa take the following points as follow:

a. Components of NahShorNa

a) Layout design. Layout design in this application takes some principles of simple, elegant, and attractive. The color of layout is beautiful color.

b) Text. Font on this NahShorNa is Arial Naskhi.

c) Pictures. Pictures on this application support material and makes the students to be more interactive. The aim of the pictures is to make the students more interesting and more focused in learning. By pictures, they learn by applying the material, not imagination. Pictures on this application drawn selected from references such us internet.

d) Audio. Audio on this application is located on background music.

e) Packaging. NahShorNa is able to save on flash disk, CD (Compact Disk), or others. Moreover, the benefits of this application is able to save for long term, able to disseminate through internet and able to save on memory or computer hardisk.

b. Selection of Material

Selections of material these are based on syllabus and learning aspect. Actually, in the syllabus Nabwu-Shorof material is studied at the second grade in An-Nashriyah, Bahrul 'Ulum. But, at the first grade in An-Nashriyah, Bahrul 'Ulum was studied because it has relationship 
with Arabic language learning. Above it, the researcher selected the basic Nabwu-Shorof material for second grade students because it has studied in the first grade and it is as stabilization last material so they are able to continue the next materials. This application used English and Arabic because in the first grade has applied by these two languages in the learning and next time An-Nashriyah will be applied these languages for daily activities. Learning aspect includes opening, content, guideline of media and references. Opening on this application consisted of introduction about Nahwu-Shorof science. It made by video scribe. The video explained how Nabwu-Shorof is, the reason choice the material, why used bilingual and introduction of the media. The contents on this application are based on six

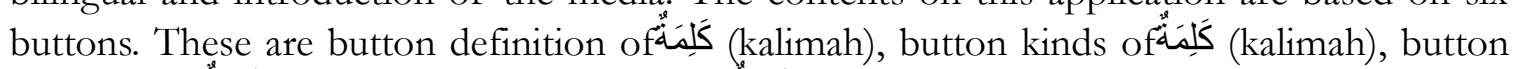

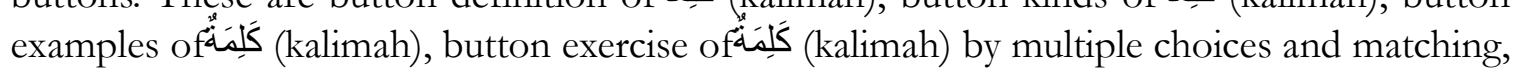
button references and button "about" of the media.The main material of this application is basic Nahwu-Shorof science. The button definition of (kalimah) is along with some

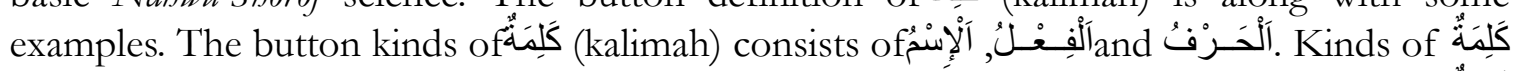
(kalimah) consist of characteristics and simple explaining. The button examples of

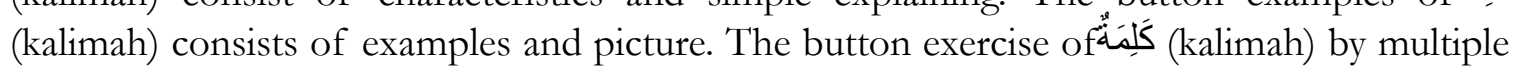
choices, matching and agglomerating. The aim of exercise is to know that the students understand about the material.

\section{The result of expert validation and revision}

On this part, the researcher discussed about the important parts of research. These are preliminary field testing and main product revision. On the preliminary field testing, it was validated by some experts. The following result is the experts' validation:

1. Expert Validation

There are three experts in this research, one media expert and two materials expert.

\section{a. Media Validation}

This validation focuses on media aspect of NahShorNa application. The expert of validation in this research is Miss. Khoiruniza Wahyundari, S.Kom, as graduation of Technology Faculty of UNIPDU Jombang. She is also as graduated from multimedia course in BLK Jombang. The questionnaire is needed to evaluate NahShorNa application. The answer of the expert is using likert's scale. The result of first step of media validation as follows: The researcher is able to calculate the total score of the questionnaire. The total score is 75 . After the researcher know the total score, next we calculated by Likert's Scale. The result is $88 \%$. Then the score used qualitative data. The score showed that the result of questionnaire based on media is "Very good" classification. Based on result of media validation, this media not needed revision.

b. Material Validation

This evaluation focuses on material aspect of NahShorNa application. The researcher needed two material experts because these used Arabic and English. The expert of English material is Mr. Hermawan, S.Pd. as English Teacher in the MAUWH, Tambak beras, Jombang. The questionnaire is needed to evaluate on English material. The answer of the expert is according to the Likert's Scale. The result of first step on the material validation as follows: The researchers are able to calculate the total score of the questionnaire. The total score is 60 . After the researcher know the total score, next we calculated by Likert's Scale. The result is $75 \%$. Then the score used qualitative data. The score showed that the result of questionnaire based on media is "Pretty good" classification. Based on result of English material validation, this application did not need revision. The expert gave addition as follow: Complete your exercise 3 so that the concept can be realized as well. The expert of Arabic material is Mr. Moh. Ilyas, Lc, M.Pd. as Arabic Teacher in the MAN 3, Tambak beras, Jombang. The questionnaire is needed to evaluate the Arabic material. The answer of the expert is according to the Likert's Scale. The result of first step on the material validation as 
follows: The researcher is able to calculate the total score of the questionnaire. The total score is 59 . After the researcher knew the total score, next we calculate by Likert's Scale. The result is $73,75 \%$. Then the score used qualitative data. The score showed that the result of questionnaire based on media is "Pretty good" classification. Based on result of Arabic material validation, this application did not need revision. The expert gave addition as follow:

a) Try more and more your Arabic writing on مهارة الكتابة in the

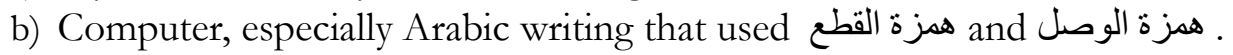

c. Revision

Before this media implemented to the students, the researcher discussed main product revision on this part so that the media is ready to used. Above result of validation, this media needed revision especially on the material validation. Although on the media validation has very good result, there are some suggestions and critiques to be constructive. After studying the suggestions, critiques, and opinion from experts, the researcher revised the last media into betterment of the media. The following figure revision from layout before and after revision:

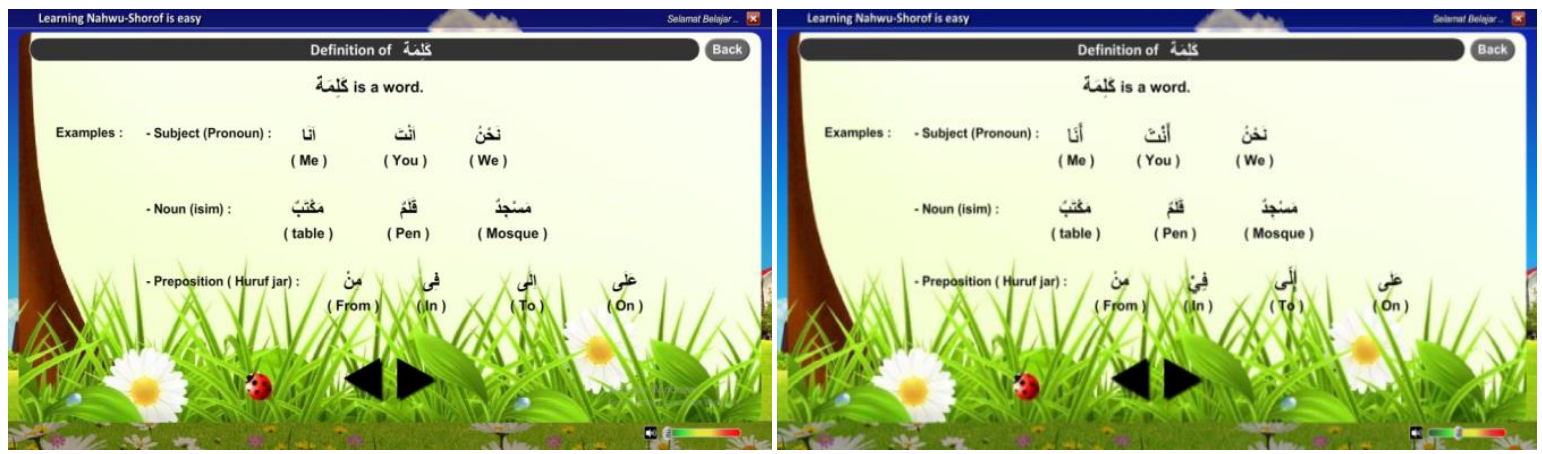

Figure 1. The layout before revision

هزة القطع There are some Arabic words that these are changed as rules.Especially, it is about and همزة الوصل. There is changed byة̈ for some words. From figure 1.1. is changed into figure 1.2 .

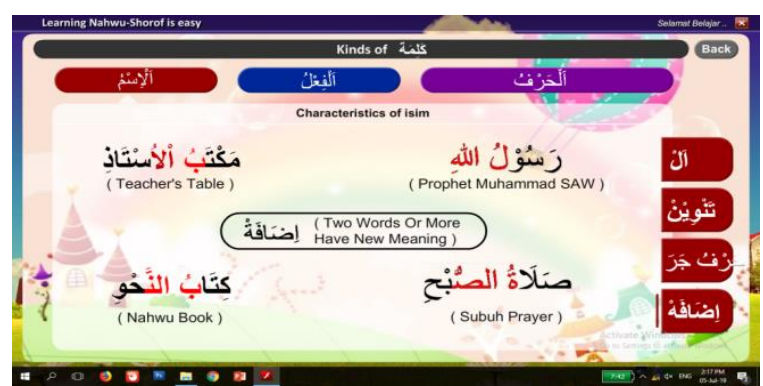

Figure 2. Arabic writing before revision

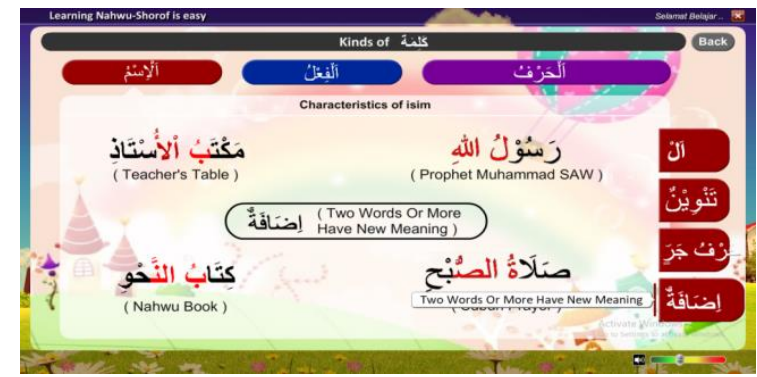

Figure 3. Arabic writing after revision 


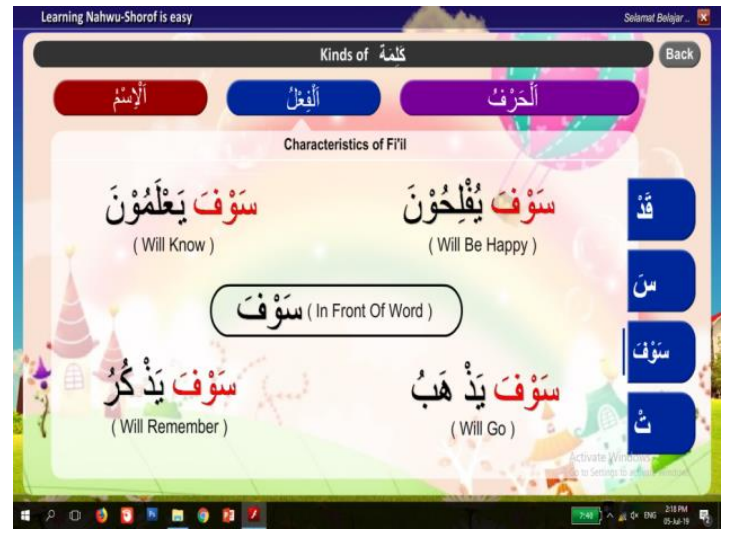

Figure 4. Arabic writing before revision

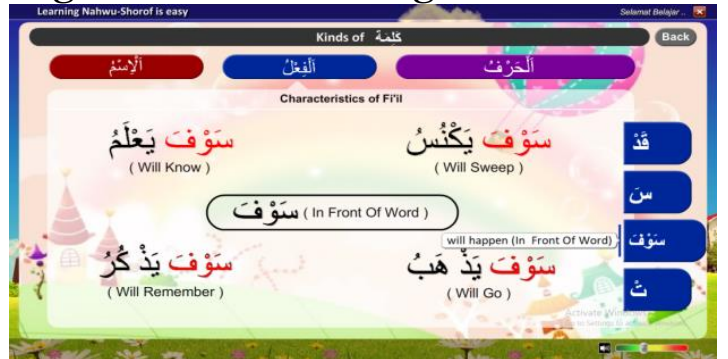

Figure 5. Arabic writing afterrevision

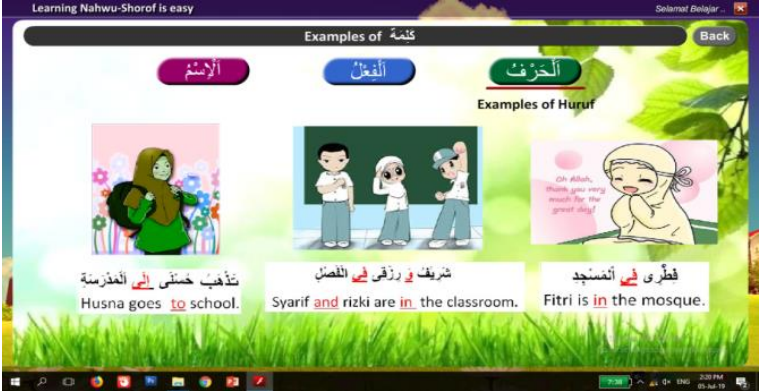

Figure 6. Arabic writing before revision

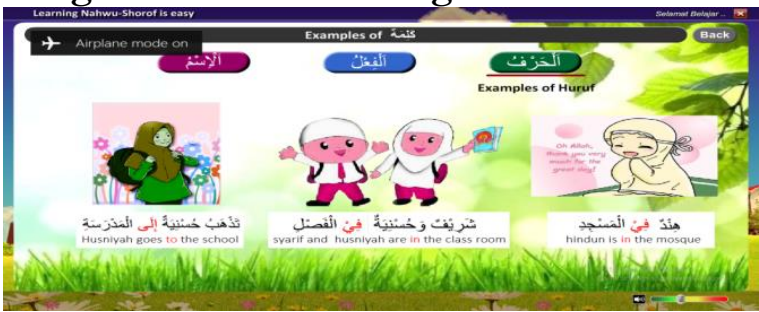

Figure 7. Arabic writing after revision

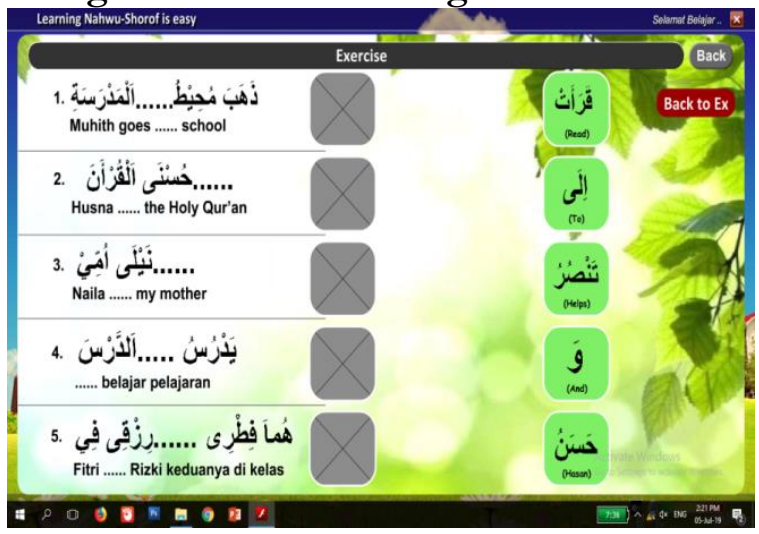

Figure 8. Arabic writing before revision 


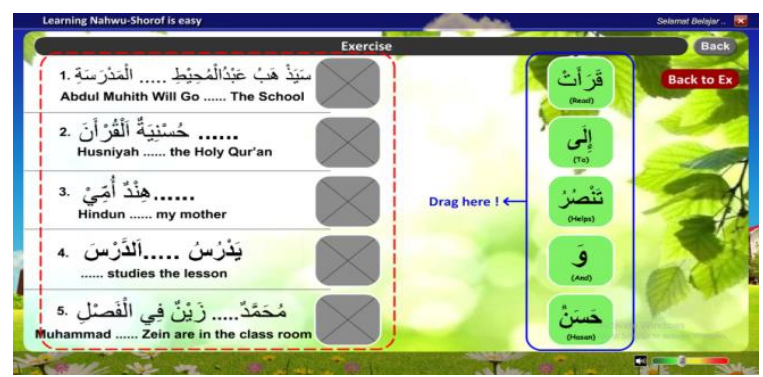

Figure 9. Arabic writing before revision

\section{The Result of Main Field Testing}

On this section, the researcher analyzed next steps of the research; these are main product testing, operational product testing and operational field testing.

1. Main field testing

On this section, the researcher had studiedthe main field testing in An-Nashriyah Islamic Boarding School Bahrul 'Ulum, Tambak beras, Jombang. There are 22 students to fill out paper sheets of sample that researched. Based on observation by the teacher for teaching and need analysis, the researcher took 12 students for research. Actually, the students consist of different ability; they are low, middle and high ability. On the main field testing, the researcher uses laptop for research to support realization of the media and more intensive than using projector because they can apply it by themselves. The activity had realization in second grade of students An-Nashriyah, Bahrul 'Ulum and used 9 laptops. So, the students try out the media as well regulated. While realization, the students have feeling comfortable and more fervently when learning. Although some of them are still confused what it means, but they are enjoyed for using the media. The students have filled questionnaires as response of using the media. The questionnaires consisted of some statements that it can determine quality of the media.

Based on Preliminary field testing, the researcher concluded that 12 students are interested Nabwu-Shorof learning used NahShorNa media and they are not bored to learn. Although, some students feel confused on how to operate it and they needed still guided by teacher. It means that the NahShorNa media is "Good" category and no needed revision. So, researcher continued to the operational field testing.

On the operational field testing, the media were tested to the small group; they are 12 students of second grade. On this step, the students fill out the questionnaire as responses of using the media. The researcher summarized that they can enjoyed and enthusiasm using NahShorNa media and they are interested in Arabic learning especiallyNabwu-Shorof learning using bilingual by technology media. Most of them expressed that NahShorNa media can support and improve spirit of learning process.

\section{Final Product}

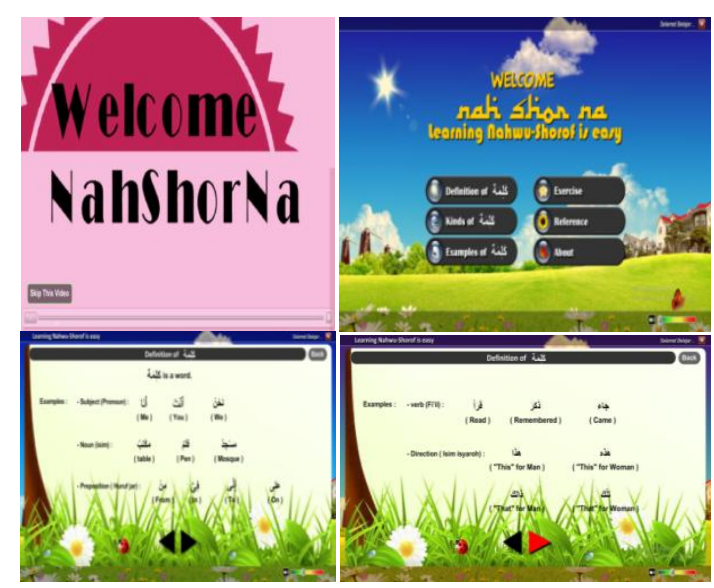




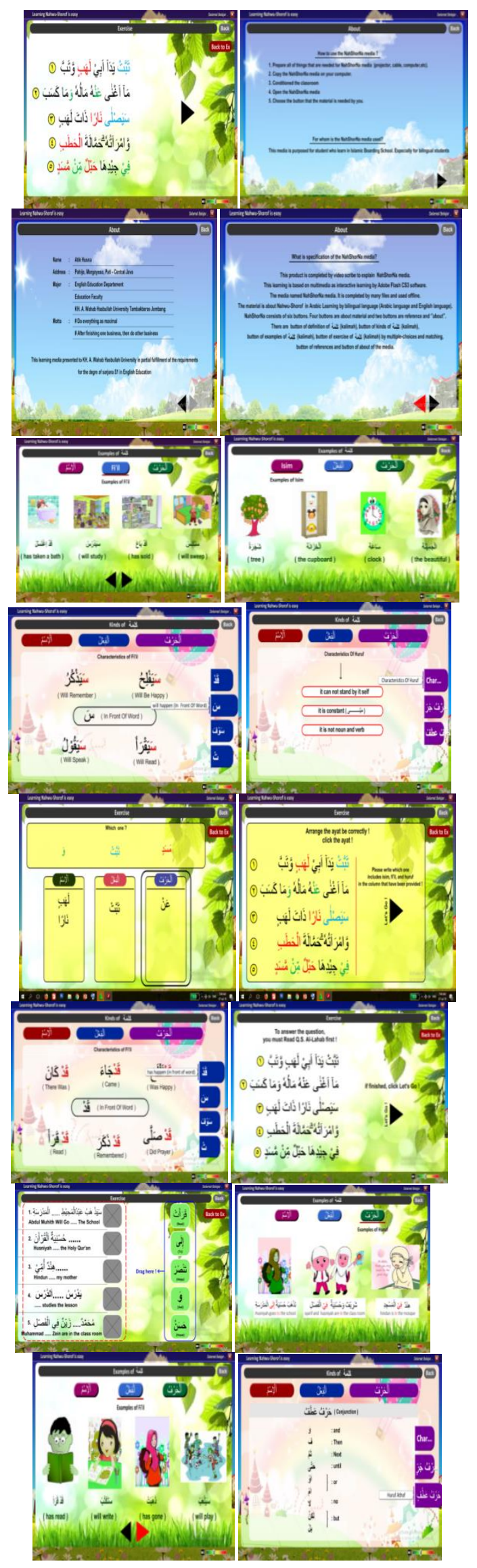




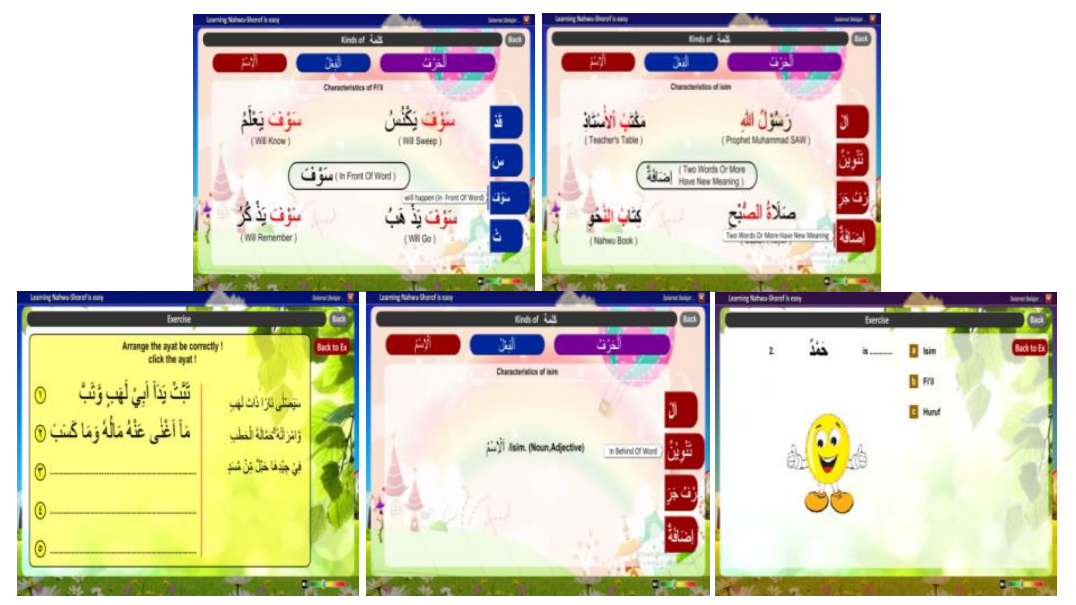

\section{CONCLUSION}

Based on result of research and analysis, the researcher concluded that the NahShorNa media is interesting to learn. It can awake student's motivation to use than as usual in Nahwu-Shorof learning because they feel that the learning has different atmosphere. The feasibility based on:

1. The result of media validation is $88 \%$ score in very goodcategory.

2. The result of two Materials validation is pretty good categories. The English material is $75 \%$ score in pretty good category. The Arabic material is $73,75 \%$ score in pretty good category.

3. The result of user validation in preliminary field study is "Good" response. Most of students are interested, enjoyful and enthusiasm with NahShorNa media because for learning using book media never using technology media. So, they feel that the learning has different atmosphere. Although some students feel the media is not easy to learn because it uses bilingual but they suggested that the media made them more enthusiasm for learning.

In this part, the researcher gives suggestions for some sides:

1. The Institution

The researcher hopes that the institution has more technology facilities to support the learning process so that the students are more enthusiasm and became active student.

2. The Teacher

The learning must be supported by professional teachers because they determine learning clearly and success. This media is hoped that it can advocate for learning and the teacher just becomes guidance the students when learning.

3. The Students

The researcher hopes that the students can be more active and have to spirit when learning because the success in future is determined by young men now. The suggestion that the students use is the media as well and can using the media autodidact. Researcher hopes that it should be better if the students use bilingual at all of lessons.

4. The Future Researcher

The researcher hopes that the future researcher can complete this media because this media is perfect less. Besides, the future researcher can implement this media on any sides so that this media can be useful when learning as well.

\section{ACKNOWLEDGEMENTS}

We would like to thank to all the authors who had already contributed to this paper and to the anonymous reviewers for their valuable comments. 


\section{REFERENCES}

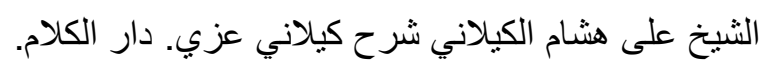

Mudah Belajar Membaca Kitab.2016. Sidogiri: Batartama.

Anggraini, Friska Agustia. 2014. Developing English Multimedia Based Teaching Media by Using Adobe Flash CS3 for VII Grade of MTs Al Huda Bandung Tulungagung. Bandung Tulungagung: IAIN Tulungagung.

Burhanuddin, Afid. 2013. Pengumpulan Data dan Instrument

Penelitian,(Online),(https://afidburhanuddin.wordpress.com/2013/05/21/pengumpulandata- dan-instrumen-penelitian-3/)

Hakim, Taufiqul. 2001. Program Pemula Membaca Kitab Kuning (st/Metode Praktis Mendalami Al-Qur'an dan Membaca Kitab Kuning. Jepara: Ponpes Darul Falah.

Latief, Muhammad Adnan. 2016. Research Methods on Language Learning An Introduction. Malang: UM.

Mukhoyyaroh, Ummi. 2018. Developing English Arabic Basic Grammar Bilingual Module for Students of Eleventh Grade of MA Salafiyah Kajen Pati (Thesis). Semarang: Walisongo State Islamic University.

Novita, Sari Sami, et al. 2016. Interactive Learning Media for Lenses and Their Applications Using Macro Visual Basic in Microsoft Power Point Faculty of Mathematics and Natural Science Institute Technology Bandung 2016.

Oxford Learner's Pocket Dictionary. 2011. Fourth Edition. New York: Oxford University Press.

Sari,Ana Wahyuning. 2017. Analisis Kesulitan Pembelajaran Nabwu Pada Siswa Kelas VIIIMTs Al Irsyad Gajah Demak Tahun Ajaran 2015/2016.Journal of Arabic Learning and Teaching,6(1), ISSN: 22526994

Sari, Ana Wahyuning. 2016. Analisis Kesulitan Pembelajaran Nabwu Pada Siswa Kelas VIIIMTs Al Irsyad Gajah Demak Tabun Ajaran 2015/2016. A Thesis. Semarang: Fakultas Bahasa dan Seni Universitas Negeri Semarang.

Sugiyono. 2014. Metode Penelitian Pendidikan. .Bandung: ALFABETA.

Yunus, Mahmud. Januari 1972. Kamus Arab-Indonesia. Jakarta: Mahmud Yunus wa Dzurriyah. 